\title{
KAJIAN NILAI-NILAI KERUKUNAN ANTARUMAT BERAGAMA DI DESA BUDUK (PEMANFAATANNYA DALAM PENGAYAAN PEMBELAJARAN IPS DI SMP N 3 MENGWI, BUDUK, KABUPATEN BADUNG)
}

\author{
Saverinus Kalut ${ }^{1}$, Sukadi ${ }^{2}$, I Wayan Kertih ${ }^{3}$ \\ Program Studi Pendidikan IPS Universitas Pendidikan Ganesha, Singaraja \\ e-mail: $\underline{\text { Saverinus Kalut }{ }^{1} \text {, Sukadi }{ }^{2} \text {, I Wayan Kertih }}{ }^{3}$
}

\begin{abstract}
Abstrak
Penelitian ini dilatarbelakangi adanya upaya untuk mewujudkan pembelajaran IPS yang inovatif yang berwawasan lingkungan yang berorientasi pada pengetahuan dan nilai-nilai lokal kerukunan antarumat beragama. Penelitian ini bertujuan: (1) memahami latarbelakang pengintegrasian pengetahuan dan nilai-nilai lokal kerukunan antarua beragama sebagai sumber belajar IPS, (2) mengidentifikasikan pengetahuan dan nilai-nilai lokal kerukunan yang ada di Desa Buduk, (3) menemukan model atau cara mengintegrasikan pengetahuan dan nilai-nilai lokal kerukunan antarumat beragama. Penelitian ini menggunakan rancangan penelitian kualitatif dengan studi etnografi pendidikan. Teknik pengumpulan data yang digunakan adalah observasi, wawancara dan dokumentasi. Teknik analisis data meliputi analisis domain, taksonomi, komponensial dan tema budaya. Hasil penelitian menunjukkan beberapa hal, yaitu: (1) Pengetahuan dan nilai-nilai kerukunan antarumat beragama sangat penting untuk dijadikan sebagai sumber belajar IPS karena pesan moral tentang hidup rukun dalam masyarakat majemuk. (2) pengetahuan dan nilai-nilai lokal kerukunan antarumat beragama yang berpotensi sebagai sumber belajar IPS meliptui: Menyama Braya, Subak, dan Banjar sedangkan nilai-nilai kerukunan antarumat beragama yang dapat dijadikan materi pembelajaran IPS adalah nilai saling percaya, gotong royong, saling menghormati, kekeluargaan, dan solidaritas, (3) pengintegrasian pengetahuan dan nilai-nilai lokal kerukunan antarumat beragama berdasarkan potensi utama, dalam bentuk perangkat pembelajaran.
\end{abstract}

Kata Kunci: Kerukunan, Kondisi Pembelajaran, Materi Pembelajaran IPS berbasis Pengetahuan dan Nilai-nilai Lokal Masyarakat.

\section{Abstract}

This research is the background of this effort to realize innovative IPS learning that oriented to the knowledge and values of local harmony among religious followers. This study aims to: (1) understand the background of integrating knowledge and local values of harmony between religions as a learning resource for IPS, (2) identifying local knowledge and values of harmony in Buduk Village, (3) finding models or ways of integrating knowledge and local values of harmony among religious believers. The research design used qualitatively with the study of educational ethnography. Data collection techniques used are observation, interview and documentation. The results of research show several things, namely: (1) Knowledge and values of harmony between religious believers is very important to serve as a source of IPS learning because of the moral message about living in harmony in a plural society. (2) knowledge and local values of harmony among religious believers that have potential as a learning resource for IPS: Brama, Subak, Banjar, mutual trust, mutual trust, mutual respect, kinship and solidarity, (3) integration of knowledge and values local harmony among religious believers based on the main potential, in the form of learning tools.

Key Words: Harmony, Learning Conditions, IPS-based Learning Materials and Local Community Values.

\section{PENDAHULUAN}

Bangsa Indonesia adalah bangsa yang majemuk, yang memiliki beragam agama, budaya, adat-istiadat dan etnik masyarakat. Keberagaman agama, budaya dan etnis merupakan modal bagi bangsa Indonesia yang dapat membawa bangsa ini menuju kejayaan (Lasmawan, 2016: 260). Namun di sisi lain, keberagaman dapat menjadi ancaman integrasi dan keutuhan bangsa. Berbagai fenomena konflik yang melanda negeri ini berawal dari halhal sepele kemudian dibesar-besarkan sehingga memicu terjadinya konflik berskala besar di mayarakat. Lebih ironis lagi, agama tidak jarang dilibatkan dan bagi sebagian orang menjadi alasan keterlibatan mereka di dalam konflik untuk membela agama. Akibatnya eksistensi agama sebagai pembawa perdamaian menjadi rusak. Agama diperalat untuk 
mengkambinghitamkan orang lain dan menimpakan kesalahan kepada orang sehingga jurang perbedaan di antara agama, etnik, dan sosial-budaya masyarakat semakin lebar. Tentu saja hal ini dapat menyebabkan gesek-gesekan di antara umat beragama tidak dapat terhindarkan.

Ketegangan-ketegangan dan gesek-gesekan tersebut dapat menyebabkan munculnya konflik horizontal yang di dalamnya melibatkan masyarakat yang berbeda keyakinan, budaya dan etnik. Relevan dengan itu, masyarakat dengan mudah menggiring suatu persoalan ke arah konflik yang bernuansa suku, agama, ras dan antargolongan (SARA). Manakala suatu persoalan sudah masuk dalam kategori konflik SARA, maka sangat gampang bagi kelompok masyarakat tertentu (biasanya kelompok mayoritas) melakukan tindakan kekerasan dan main hakim sendiri atas dasar justifikasi kebenaran atau keyakinan kelompok sendiri.

Tentu saja hal semacam ini adalah sesuatu yang keliru yang dapat memicu disintegrasi bangsa dan negara. Ada banyak contoh dimana fenomena disintegrasi berkembang saat ini seperti peristiwa bom bunuh diri di lingkungan gereja, konflik etnis di Sambas Kalimantan, konflik antaragama dan antarsuku di Lampung, dan yang lainnya di Indonesia. Ironisnya, justru masalah yang tidak memiliki keterkaitan dengan agama itu kemudian direduksi seolah-olah menjadi seolah-olah persoalan agama. Akibatnya fenomena yang mencuat ke permukaan adalah permasalahan agama. Hal ini dapat memicu ketegangan di antara umat beragama.

Manakala hal itu yang terjadi, memang ibarat api di dalam sekam di mana mulai banyak muncul kelompok intoleransi dan radikalisme yang mengatasnamakan agama tertentu dan ikut memperkeruh suasana. Hal ini tentu saja mempersulit terciptanya kehidupan bersama yang rukun di tengah-tengah masyarakat. Mengenai fenomena ini sebagian orang menimpakan kesalahan tersebut kepada pihak-pihak yang dengan segaja memprovokasi dan memanfaatkan kesempatan untuk tujuan politis mereka. Dan sebagian lagi mengatakan bahwa fenomena semacam ini dianggap sebagai sesuatu yang biasa dan wajar terjadi di dalam kehidupan masyarakat yang majemuk.

Seyogianya, masyarakat haruslah lebih berpikir dengan cerdas bahwa pendapat semacam ini bisa ada benarnya dan bisa juga hanya sebagai rekayasa. Yang perlu untuk dilakukan pada situasi semacam ini adalah menunjukkan kebenaran yang terkandung dalam doktrin agama sehingga agama yang pada hakikatnya sebagai pembawa perdamaian tidak dimanipulasi untuk tujuan politis golongan, kelompok dan orang-orang tertentu. Sebab agama adalah sebuah institusi yang memiliki kredibilitasnya dan wibawa yang menjunjung tinggi nilai-nilai kebenaran, keadilan dan moralitas.

Kehidupan berbangsa dan bernegara saat ini memang sedang mengalami persoalan disintegrasi yang seakan bernuansa SARA, tetapi kita masih memiliki harapan untuk memertahankan integrasi bangsa dengan bercermin pada fenomena menarik kerukunan antarumat beragama di Desa Buduk. Secara sosio-historis penduduk Desa Buduk berasal dari berbagai latar belakang agama, budaya dan etnis masyarakat yang kemudian berintegrasi satu sama lain. Berdasarkan hasil studi pendahuluan diperoleh data bahwa di Desa Buduk terdapat 5 (lima) agama besar di antaranya Hindu, Protestan, Islam, Katolik dan Budha. Dari 5 (lima) agama besar ini terdapat jumlah umat yang berbeda-beda pula (Profile Desa Buduk 2017). Menariknya walau beragam agama, budaya dan etnis, masyarakat Desa Buduk justru tetap menjunjung tinggi kerukunan sebagai nilai tertinggi. Pesan kerukunan yang disampaikan oleh leluhur masyarakat Desa Buduk telah diwariskan kepada generasi baru dengan harapan kerukunan menjadi nilai yang sanggup memperstukan semua orang dari bermacam latarbelakang.

Terintegrasinya masyarakat ke dalam suatu komunitas tertentu, oleh Nasikun (1998) dan Geertz (1981) dikatakan dapat terjadi karena adanya kesepakatan akan nilai-nilai budaya yang bersifat fundamental (Pageh, 2013:193). Dalam hubungan ini, di samping pengetahuan dan nilai-nilai masyarakat tentang Pancasila, pengetahuan dan nilai-nilai lokal kerukunan antarumat beragama yang tumbuh dan berkembang pada masyarakat Desa Buduk juga merupakan pengetahuan dan nilai-nilai budaya yang bersifat fundamental. Dikatakan fundamental karena sudah terbukti membentuk karakter masyarakat Desa Buduk 
yang rukun dan toleransi satu dengan yang lainnya. Karena itulah menurut pandangan peneliti sesuatu yang sangat baik jika pengetahuan dan nilai-nilai kerukunan antarumat beragama di Desa Buduk diintegrasikan ke dalam pendidikan sehingga dapat menangkal konflik dan perkembangan ideologi intoleransi dan radikalisme.

Pendidikan sebagai wadah pembudayaan memiliki kedudukan yang sangat strategis terhadap upaya pembinaan masyarakat tentang integrasi bangsa dengan cara membina masyarakat dengan pengetahuan dan nilai-nilai lokal kerukunan antarumat beragama. Peran strategis pendidikan ini akan sanggup menjalankan fungsinya dalam membentuk karakter masyarakat ke arah yang lebih baik. Dengan demikian fungsi pendidikan sebagai alat pembudayaan pengetahuan dan nilai-nilai lokal dapat menghantar masyarakat merasa memiliki budayanya sendiri dan tidak kehilangan pengetahuan dan nilai-nilai lokalnya sebagai sandaran kehidupannya manakala berada pada lingkungan masyarakat yang majemuk (Tilaar, 2000: 30). Hal ini sejalan dengan Mudyahardjo (2009: 3) yang mengemukakan bahwa pendidikan merupakan usaha manusia untuk membina kepribadiannya dengan berlandaskan pada kebudayaan masyarakat. Artinya kebudayaan itu sesuatu yang tak terpisahkan dalam proses pembentukan jati diri masyarakat.

Masyarakat Desa Buduk adalah masyarakat yang beragam agama dan budaya. Tentu saja mereka senantiasa mendasari kehidupan mereka pada budaya dan agama yang diwariskan leluhur mereka. Karena itu semestinya pengetahuan dan nilai-nilai lokal kerukunan antarumat beragama yang bersumber pada budaya masyarakat lebih ditonjolkan sehingga mayarakat tidak kehilangan budaya kerukunan dalam kehidupan bersama. Karena itu proses pendidikan bukanlah proses yang bersifat statis yang hanya hidup dalam periode dan waktu tertentu melainkan berkembang dari satu periode ke periode berikutnya melalui pewarisan. Melalui proses yang berkesinambungan pewarisan pengetahuan dan nilai-nilai lokal kerukunan antarumat beragama diaggap sebagai bentuk usaha pengakaran budaya, agama dan adat-istiadat ke dalam diri masyarakat sehingga antara budaya, agama dan masyarakatnya tidak terjadi kesenjangan. Pada titik ini sekolah dipandang sebaga pusat budaya dimana sekolah menjadi tempat mengejawantahkan pengetahuan dan nilai-nilai lokal masyarakat kepada para peserta didik. Sekolah dituntut mampu mengakomodir pengetahuan dan nilai-nilai lokal masyarakat sehingga eksistensi sekolah sebagai Wiyata Mandala di mana terjadinya proses pendidikan, proses transformasi kebudayaan, pelestarian pengetahuan dan nilai-nilai kearifan lokal dapat terwujud.

Sekolah, di sisi lain, dihadapkan pada persoalan kebijakan kurikulum pendidikan yang dari tahun ke tahun tersentralistik. Masalah sentralistik pendidikan nasional telah banyak disoroti dalam berbagai pembicaraan dan forum diskusi (Tilaar, 2001: 210). Sistem kurikulum yang sentralistik itu, menunjukkan bahwa pendidikan di Indonesia masih terjebak dalam praktik dominasi dan hegemoni yang cenderung mengabaikan nilai-nilai kearifan lokal terutama tentang nilai-nilai kerukunan antarumat beragama. Dengan kurikulum yang tersentralistik, dunia pendidikan seakan-akan dikuasai oleh ideologi kapitalis, materialisme dan menampakkan gejala sekularisasi di mana nilai-nilai moral-religius tergerus arus zaman. Terdapat kecenderungan di dalam dunia pendidikan saat ini memisahkan antara ideologi agama dan ideologi pengetahuan. Fenomena seperti ini tampak dalam aktivitas belajar di dalam kelas dimana nilai-nilai religius sebagai nilai dasar sebagai insan rohani kurang mendapat perhatian oleh para pendidik. Yang terjadi ialah banyak sekolah berlomba-lomba dalam upaya peningkatan kecerdasan intelektual semata (Sukadi, dkk., 2009: 3). Praktik dominasi dan hegemoni kebijakan pendidikan nasional tersebut justru tidak membawa perubahan tetapi terjadi pembatasan otonomi sekolah dan tidak jarang persoalan semacam ini para pengambil kebijakan pendidikan menimpakan krisis mutu pendidikan kepada sekolah-sekolah (Kertih, 2012: 17).

Belum lagi persoalan keterbatasan daya profesionalisme yang masih banyak dihadapi oleh lembaga pendididikan kita di mana sekolah-sekolah belum memiliki daya kemampuan inovasi dan kreativitas untuk mengembangkan materi pengajaran, termasuk IPS, dengan mengakomodir pendidikan berbasis pengetahuan dan nilai-nilai lokal. Pengetahuan dan nilai-nilai lokal dapat dipahami sebagai gagasan, nilai, pandangan masyarakat setempat yang bersifat bijaksana, penuh kearifan, bernilai baik, yang tertanam 
dan diikuti oleh anggota masyarakat. Pengetahuan dan nilai-nilai kearifan lokal kerukunan antarumat beragama merupakan gagasan, nilai, kebijaksanaan, dan kearifan lokal masyarakat yang ikut membantu membentuk kerukunan yang perlu diajarkan di sekolah melalui Pendidikan IPS. Pendidikan IPS di sekolah semestinya harus membekali para peserta didik dengan pengetahuan dan nilai-nilai kerukunan antarumat beragama selain untuk membendung laju perkembangan ideologi-ideologi baru serentak supaya eksistensi pengetahuan dan nilai-nilai budaya tidak tercabut dan menjadi punah. Upaya pengintegrasian pengetahuan dan nilai-nilai lokal kerukunan antarumat beragama sebagai upaya merekonstruksi kembali pola belajar mengajar yang masih cenderung mengabaikan lingkungan masyarakat sebagai bagian dari medan belajar para guru dan peserta didik. Nursid Sumaatmaja (Gunawan, 2013:13) menerangkan bahwa upaya pengintegrasian merupakan upaya membentuk karakter para peserta didik dalam menghasilkan generasi yang memiliki pengetahuan, keterampilan sikap sosial, nilai, dan sikap moral sebagai warga negara yang baik. Sedangkan secara rinci Omar Malik merumuskan tujuan pendidikan IPS berorientasi pada tingkah laku para siswa, yaitu: (1) pengetahuan dan pemahaman, (sikap hidup belajar), (2) nilai-nilai dan sikap sosial, (3) keterampilan sosial (Hamalik, 1992: 40). Selain itu, jika berorientasi pada pengembangan tujuan social studies yang diterapkan oleh National Council for Social Studies (NCSS), maka dalam kaitannya dengan tujuan pembelajaran pendidikan IPS di Indonesia yang disesuaikan dengan kurikulum, maka pembelajaran IPS mempunyai tujuan yaitu memiliki komitmen dan kesadaran terhadap nilainilai sosial dan kemanusian.

Pengintegrasian pengetahuan dan nilai-nilai lokal diharapkan menjawab permasalahan konvensionalitas dan tradisionalitas dalam pembelajaran IPS yang masih terbatas dan lemah (Lasmawan (2010: 93). Di satu pihak para siswa dijejali dengan beraneka ragam pengetahuan ilmiah tentang masyarakat, sementara di pihak lain pengetahuan tersebut belum tersusun dengan baik. Berkenaan dengan hal ini, maka perlu menyajikan sumber-sumber belajar yang kontekstual, aktual dan relevan dengan kehidupan masyarakat dan pengalaman para peserta didik sendiri. Terdapat banyak fenomena menarik di masyarakat yang dapat diintegrasikan ke dalam pembelajaran IPS sehingga para guru dan wawasan pengetahuan peserta didik dapat diperkaya. Tujuan lain dari pembelajaran berbasis lingkungan masyarakat sebagai sumber belajar adalah agar para guru dan peserta didik memiliki kemampuan bersosialisasi, bereksplorasi, dan berkolaborasi dengan lingkungan sosial kemasyarakatan. Mereka harus bisa menjalin relasi dengan masyarakat sekitar sehingga terdapat korelasi antara harapan dan kenyataan dalam pembelajaran IPS itu sendri. Dengan demikian dapat mematahkan stigma kesenjangan pembelajaran IPS yang masih jauh dari realitas kehidupan sosial kemasyarakatan dan kecenderungan yang dilakukan oleh guru yang selalu mengandalkan buku teks sebagai satu-satunya sumber bahan ajar. Padahal sumber belajar IPS tidak hanya dari sumber-sumber tertulis tetapi juga terdapat sumber lisan seperti tradisi-tradisi, ritual-ritual suci dalam adat istiadat masyarakat serta aneka habitus yang dipertahankan oleh masyarakat dalam hubungan dengan yang ilahi, sesama dan kosmos. Menggunakan masyarakat sebagai sumber belajar berarti guru dan para peserta didik berusaha menggali, menemukan dan memanfaatkan pengetahuan yang ditemukan sehingga lingkungan masyarakat menjadi mitra belajar para guru dan siswa untuk memperluas kajian ilmu pengetahuan mereka. Alasan yang menyebabkan pembelajaran IPS kurang memanfaatkan pengetahuan dan nilai-nilai lokal menurut Gunawan (2013: 83-84) disebabkan oleh konvensionalitas proses, menonjolkan transformasi fakta dan konsep-konsep yang kurang menarik serta cenderung mengejar target. Sehingga tidak heran kalau isi dari pembelajaran IPS membosankan dan kurang memberikan stimulus yang dapat meningkatkan gairah belajar yang lebih pada diri peserta didik. Menurut Drost (1998: 49) pembelajaran IPS menjadi kurang menarik sebagian besar para pendidik, karena para guru IPS kurang dibekali dengan pendidikan klasik. Pendidikan Negara berkembang seperti Indonesia masih mementingkan pendidikan eksakta dan teknologi. 


\section{METODE}

Penelitian ini menggunakan rancangan penelitian kualitatif. Metode penelitian kualitatif, yakni penelitian yang dinyatakan dengan kata-kata atau yang sering juga disebut metode penelitian interaksi simbolik, fenomenologis maupun studi kasus (Atmadja, 2006) dalam Padma (2015). Menurut Creswell (1998) penelitian diklasifikasi dalam 5 (lima) tradisi studi, di antaranya penelitian biografi, fenomenologi, Grounded Theory, studi etnografi, dan studi kasus. Terkait dengan itu, kajian nilai-nilai kerukunan antarumat beragama di Desa Buduk jika dimasukkan dalam tradisi studi kualitatif Creswell dapat termasuk dalam tradisi studi etnografi, sebab obyek kajian melingkupi suatu kelompok/komunitas masyarakat tertentu yang memiliki agama, budaya, adat-istiadat, etnik, nilai-nilai, tradisi, ritual, norma dan hukum yang berlaku dalam suatu kelompok masyakat. Karena itu, menurut Muhadjir (2007:47) penelitian etnografi adalah suatu deskriptif mengenai cara berpikir, hidup, dan perilaku suatu masyarakat. Neyland (dalam Sarosa, 2013:128) berpendapat bahwa penelitian etnografi adalah suatu model penelitian yang menggunakan pengamatan dan partisipasi di dalam kelompok masyarakat tertentu. Alasan penggunaan pendekatan etnografi dalam penelitian ini karena fokus peneliti ingin menjelaskan dan mendeskripsikan secara mendetail tentang fenomena budaya kerukunan antarumat beragama yang dapat dikontruksi menurut persepsi partisipan penelitian secara alamiah. Fenomena budaya yang dimaksudkan di sini ialah berkenaan dengan keyakinan iman, nilai-nilai, norma, adat-istiadat, penggunaan simbol-simbol dan praktik dalam kehidupan sehari-hari oleh masyarakat (Muhadjir, 2007: 48). Dalam penelitian ini fenomena yang diteliti terkait dengan nilai-nilai budaya yang dihidupi oleh masyarakat Desa Buduk. Nilai-nilai tersebut merupakan nilai budaya kerukunan antarumat beragama di Desa Buduk Kecamatan Mengwi-Kabupaten Badung-Provinsi Bali, yang telah diwariskan secara turun termurun sehingga menjadi milik kepunyaan warga masyarakat Desa Buduk. Adapaun hal-hal yang mendorong peneliti melakukan penelitian ini adalah fenomena kerukunan antarumat beragama yang ada di Desa Buduk yang sangat rukun dan toleransi. Walau masyarakat Desa Buduk berbeda keyakinan agama, budaya dan berbeda etnik, tetapi mereka dapat membangun komunitas masyarakat yang rukun dan damai. Hal ini tentu menjadi berbeda dengan kehidupan beragama di banyak tempat di Indonesia yang belakang ini mengalami pasang surut dan seringkali terjadi konflik.

Subyek atau informan dalam penelitian ini meliputi Kepala Desa Buduk, tokoh agama, tokoh masyarakat, guru IPS, dan siswa. Latarbelakang pemilihan informan tentu terkait dengan kapasitas mereka sebagai orang-orang memiliki kredibilitas dalam memberikan informasi yang memadai tentang kerukunan antarumat beragama di Desa Buduk dan pembelajaran IPS. Sedangkan obyek material dari penelitian ini adalah kajian nilai-nilai kerukunan antarumat beragama di Desa Buduk dan pemanfaatannya dalam pembelajaran IPS di SMP. Dalam kaitan dengan itu, dalam memperoleh data penelitian, pendekatan yang relevan untuk digunakan adalah wawancara, observasi dan studi dokumentasi. Data-data itu kemudian diolah dan dideskripsikan untuk kemudian diinterpretasi makna yang terkandung di dalamnya sehingga memperoleh suatu jawaban pasti terkait dengan fenomena yang sedang diteliti. Hal yang tidak dapat diabaikan dalam proses tersebut adalah peneliti melakukan pengujian atas keabsahan data penelitian dengan menggunakan teknik: 1) triangulasi sumber data, 2) triangulasi metode, 3) triangulasi teori. Selanjutnya data-data yang sudah ditentukan dalam domain-domain dalam penelitian oleh peneliti kemudian dianalisis lebih lanjut dengan menggunakan tahap-tahap analisis etnografi meliputi: 1) analisis domain, 2) analisis taksonomi, 3) analisis komponensial, dan 4) analisis tema budaya.

\section{HASIL DAN PEMBAHASAN}

\section{Kerukunan Antarumat Beragama di Desa Buduk}

Dengan menggunakan pendekatan atau analisis kualitatif etnografis, selanjutnya data yang terkait dengan fokus penelitian dianlisis dan dibahas dengan berbagai konsep/teori yang relevan untuk itu. Berdasarkan analisis data dapat dipahami bahwa sumber kekuatan yang mempersatukan masyarakat Desa Buduk adalah kesanggupan mereka dalam 
mengamalkan pengetahuan dan nilai-nilai lokal yang dimiliki oleh masyarakat. Pengetahuan dan nilai-nilai lokal yang ada bersumber pada agama, budaya dan adat-istiadat yang kemudian diwariskan turun-temurun oleh leluhur kepada masyarakat Desa Buduk sehingga memberikan berpengaruh terhadap pola prilaku masyarakat terutama dalam menanggapi perubahan-perubahan sosial. Masyarakat yang terintegrasi dalam kesatuan sosial selain memiliki latarbelakang agama, budaya, adat istiadat dan etnis yang berbeda tetapi mereka dapat berinteraksi satu sama lain. Dalam perjumpaan itu, masyarakat yang berasal dari kultur yang berbeda perlahan-lahan saling berbaur dan mengalami perubahan perilaku karena masuknya unsur-unsur kultur baru.

Namun, masuknya kultur budaya baru, tidak serentak menghilangkan budaya asli masyarakat sebaliknya masyarakat masing-maing mempertahankan keaslian budaya masing-masing dan juga tetap menerima pengaruh dari luar. Sikap insklusif masyarakat Desa Buduk terhadap kultur baru yang dibawa oleh para pendatang justru menjadikan kehidupan bersama lebih dinamis. Masyarakat Desa Buduk tidak menjadi sebuah komunitas anti perubahan tetapi mereka menerima perubahan itu sebagai sebuah realitas dalam kehidupan bermasyarakat di dunia post-modern ini. Walau secara sosio-historis masuknya para pendatang di Desa Buduk menimbulkan persoalan bagi warga masyarakat lokal. Namun dalam perjalanan persoalan ditemukan jalan keluarnya dan sekarang masyarakat Desa Buduk dapat hidup berdampingan secara damai. Alhasil, masyarakat Desa Buduk semakin menyadari pentingnya sebuah perubahan. Perubahan itu ditunjukkan melalui proses pembauran, beradaptasi dan terintegrasi sehingga dapat menerima perbedaan. Hal ini kemudian diperkuat dengan adanya nilai-nilai, norma, hukum dan kesepakatankesepakatan bersama menjadi fungsi kontrol bagi masyarakat Desa Buduk dalam membangun hubungan sosial dengan sesama. Dengan adanya pengetahuan lokal dan nilainilai lokal yang menjadi kebijaksanaan lokal masyarakat menjadi pedoman di mana masyarakat dapat berinteraksi secara lebih dekat dengan sesama. Proses integrasi memungkinkan terjadinya interaksi sosial, misalnya penggunaan simbol-simbol budaya, agama dan kesenian lokal yang kemudian dimanfaatkan oleh masyarakat pendatang sehingga menimbulkan kesan adanya saling menerima budaya. Masyarakat menyadari proses akulturasi dan enkulturasi budaya bukanlah sesuatu yang abstrak tetapi fakta terjadi, sehingga perpaduan antara budaya masyarakat lokal dengan kultur budaya asing dapat semakin nyata terjadi.

\section{Pengetahuan-pengetahuan Lokal Kerukunan Antarumat Beragama di Desa Buduk yang dapat Dimanfaatkan untuk Pengayaan Pembelajaran IPS.}

Desa Buduk secara geografis terletak cukup jauh dari pusat perkotaan. Kehidupan masyarakat masih sangat bernuansa pedesaan. Hal ini ditandai dengan sebagian besar aktivitas masyarakat adalah pertanian. Di samping aktivitas pertanian, masyarakat Desa Buduk sangat kental dengan kegiatan sosial budaya dan religius. Apalagi masyarakat Desa Buduk secara sosial adalah terkategorikan masyarakat multikultur yang memiliki keanekaragaman agama, budaya, adat istiadat dan etnik yang berbeda. Keberagaman merupakan suatu kerunikan sekaligus menjadi kekayaan umat beragama di Desa Buduk. Mereka yang berbeda keyakinan agama, budaya dan berbeda etnis justru sanggup menunjukkan suatu pola kehidupan bersama yang ideal. Hal ini tidak dapat dilepaskan dari peran agama, budaya yang melekat dalam diri masyarakatnya masing-masing yang juga turut berkontribusi dalam membangun tatanan kehidupan bersama yang rukun dan damai. Mereka yang terintegrasi dalam kesatuan sosial membentuk suatu komunitas yang didasari oleh nilai-nilai, budaya, agama, dan kebijaksanaan lokal yang telah mempersatukan seluruh warga masyarakatnya. Walaupun berbeda keyakinan, masyarakat Desa Buduk tetap memiliki keyakinan yang kuat bahwa pengetahuan lokal yang diwariskan leluhur adalah media pemersatu masyarakat.

Beberapa pengetahuan lokal masyarakat Desa Buduk yang secara substansial memiliki pengaruh dan telah membawa perubahan perilaku masyarakat di antaranya tardisi Menyama Braya, Subak dan Banjar. Ketiganya telah menjadi tradisi lokal yang telah berperan dalam mengembangkan komunitas masyarakat yang damai dan rukun. Isi daripada 
setiap pengetahuan ini sama, yaitu bagaimana mengembangkan komunitas sosial kemasyarakatan yang terintegrasi oleh perbedaan agama dan budaya dapat bertahan. Karena fungsi dan perannya dapat mempersatukan masyarakat maka kemudian pengetahuan lokal ini oleh masyarakat Desa Buduk menjadikannya sebagai media menumbuhkan tali persaudaraan dengan orang lain. Secara substansial konten dari pada ketiga pengetahuan lokal ini tidak lain bersumber pada falsafah pokok masyarakat Hindu Bali yaitu, filsafat Tri Hita Karana. Tiga poin pokok yang terkandung dalam filsafat itu melukiskan tiga lingkaran interaksi kehidupan di antaranya interaksi dengan yang ilahi, sesama dan alam semesta. Salah satu penekanan dalam falsafah itu adalah poin pentingnya menjaga relasi manusia dengan manusia. Tuntutannya ialah setiap orang harus mampu menjaga kesimbangan relasi sehingga tidak menimbulkan konflik sosial. Hubungan antara manusia harus didasari oleh semangat saling mengasihi, mencintai dan toleransi. Hal ini tentunya selaras dengan hakikat penciptaan manusia sebagai insan religius. Karena itu adalah sesuatu yang sangat relevan bahwa pengetahuan lokal mampu menciptakan tatanan kehidupan yang rukun dan toleransi karena unsur interaksi di antara manusia senantiasa dilestarikan dengan baik. Masyarakat Desa Buduk dalam tataran ini telah mengimplementasikan dimensi pawongan dalam realitas kehidupan sosial kemasyarakatan. Pengetahuan lokal menjadi pengejawantahannya sehingga nilai-nilai yang termaktub dalam kearifan lokal yang ada tidak dapat terpisah dari sumber pokoknya. Sebab falsafah Tri Hita Karana itu mengandung pesan moral universal yang kemudian direalisasikan dalam aneka bentuk pengetahuan-pengetahuan lokal masyarakatnya. Karena memiliki pesan moral universal maka semua orang mengakui dan menerimanya sebagai pengetahuan warisan leluhur yang mampu merekat seluruh warga masyarakat termasuk mereka yang berbeda budaya, agama, adat-istiadat dan etnik. Manakala pengakuan atas eksistensi pengetahuan lokal pengetahuan pemersatu semua warga masyarakat, maka serentak pula hubungan sosial kemasyarakat menjadi rukun dan damai. Masyarakat Desa Buduk yang tergabung dalam kesatuan sosial banjar, subak dan melakoni tradisi Menyama Braya akan selalu menempatkan relasi sosial dengan sesama menjadi sebuah prioritas. Dalam hubungan dengan hal itu, warga Desa Buduk yang tergabung dalam kesatuan sosial masyarakat telah menunjukkan relasi sosial itu baik secara konkret maupun secara simbolik. Simbol-simbol digunakan dengan tujuan memperdalam hubungan di antara warga masyarakat. Simbolsimbol itu dapat berupa verbal maupun non verbal. Simbol verbal misalnya bahasa yang diucapkan yang secara semantik dapat diinterpretasi secara luas dan memiliki makna universal dan diterima oleh masyarakat luas pula. Menyama braya, subak dan banjar adalah pengetahuan lokal masyarakat Bali yang sudah diakui dan karenanya bermakna universal dan diterima oleh semua orang.

\section{Nilai-nilai Lokal Kerukunan Antarumat Beragama di Desa Buduk yang dapat Dimanfaatkan untuk Pengayaan Pembelajaran IPS.}

Selain pengetahuan lokal terdapat dimensi nilai yang ikut berkontribusi terciptanya kerukunan di antara umat beragama di Desa Buduk. Menurut Bertens (2011) nilai merupakan alat yang menunjukkan alasan dasar bahwa "cara pelaksanaan atau keadaan akhir tertentu lebih disukai secara sosial dibandingkan cara pelaksanan atau keadaan akhir yang berlawanan". Nilai memuat elemen pertimbangan yang membawa ide-ide seorang individu mengenai hal-hal yang benar, baik, atau diinginkan. Secara substansial nilai memiliki karakteritik benar, baik dan diinginkan. Beragam nilai lokal yang dihidupi oleh masyarakat Desa Buduk yang diwariskan oleh leluhur mereka memuat prinsip-prinsip di atas. Prinsip baik, benar dan diterima oleh masyarakat juga termaktub dalam nilai-nilai lokal kerukunan antarumat beragama sehingga nilai-nilai tersebut dipertahankan oleh masyarakatnya. Prinsip-prinsip tersebut menjadi substansi isi dari nilai-nilai lokal kerukunan antarumat beragama dan menjadi landasan dalam membangun interaksi sosial dengan umat beragama lain. Karenanya nilai-nilai lokal kerukunan menjadi sarana yang mampu mempersatukan seluruh warga masyarakat Desa Buduk yang beragam latarbelakang agama, budaya dan etnik ke dalam sebuah komunitas kasih. Melalui komunitas mereka mengintegrasikan diri mereka ke dalam kesatuan-kesatuan sosial yang ada. Dari kesatuan- 
kesatuan sosial yang ada tesebut kemudian mereka berbaur, beradaptasi dan menjalin kontak sosial satu sama lain. Sehingga melalui proses itu mereka dapat bertumbuh dan berkembang dalam ikatan sosial yang satu dan sama. Mereka kemudian menghayati nilai yang satu dan sama dan sampai pada titik itu mereka telah menciptakan suatu keseimbangan (ekuilibrium) di dalam masyarakat. Kesanggupan masyarakat Desa Buduk dalam menginternalisir nilai-nilai lokal yang ada tidak terlepas dari peran agama, budaya, dan penghayatan atas praktik adat-istiadat masing-masing etnik. Melalui agama kepada setiap orang diajarkan tentang cara beragama yang baik dan benar dan menumbuhkan sikap moralitas dalam diri. Sedangkan melalui budaya masyarakat diajarkan etika hidup. Beberapa nilai lokal kerukunan antarumat beragama seperti saling percaya, gotong royong, saling menghargai, kekeluargaan dan solidaritas merupakan penjelmaan daripada dimensi agama dan budaya masyarakat. Nilai-nilai lokal tersebut kemudian menjadi pegangan hidup yang penting dan karenanya perlu dipertahankan. Selain itu, nilai-nilai lokal kerukunan secara substansial mengandung makna universal yang sanggup mengayomi seluruh warga masyarakat. Serentak pula, nilai-nilai tersebut menjadi sarana dalam mengembangkan komunikasi yang dinamis dalam komunitas Desa Buduk. Walau tergolong desa yang multikultur, mereka sanggup menunjukkan identitas pluralisme itu sebagai prioritas hidup bersama. Kepentingan bersama menjadi sebuah keharusan dan menjadi prioritas bersama masyarakat. Sehingga melalui prinsip ini, setiap agama, budaya masyarakat dan etnik memiliki kewajiban secara sosial untuk mengontrol jalannya interaksi di antara masyarakat dan mencegah terjadinya konflik sosial. Fungsi kontrol menjadi fungsi pengawasan yang melekat dalam diri setiap orang sehingga dengan demikian kehidupan bersama semakin rukun dan damai. Fungsi kontrol dijalankan terutama bagaimana mengautur interaksi sosialnya dengan memanfaatkan simbol-simbol secara baik dan benar sehingga tidak memicu disharmonis relasi di antara masyarakat. Misalnya karya seni pahat dan seni lukis yang adalah khas kesenian Bali, namun kemudian oleh Gereja Katolik menginkulturasikannya ke dalam seni bangunan gereja. Gereja sengaja mengingkulturasikan dirinya agar cita rasa evangelisasinya selaras dengan budaya masyarakat setempat. Karenaya gereja bukanlah entitas yang terpisah dari budaya masyarakatnya. Contoh lain di Desa Buduk terdapat usaha kecil dan menengah yang pelaku adalah masyarakat lokal. Masyarakat lokal ini juga berasal dari beragam latarbelakang agama, budaya, dan status sosial. Dalam kegiatan perekonomian masyarakat Desa Buduk sangat menjunjung tinggi kebebasan dan hak asasi orang lain. Mereka tidak menolak bahkan melarang siapapun untuk mengembangkan perekonomian di Desa Buduk sejauh hal itu selarah dengan nilai, norma dan hukum yang berlaku.

Beberapa contoh ini menggambarkan kehidupan bersama masyarakat Desa Buduk yang ideal yang dapat membangun kerukunan di antara umat beragama. Interaksi sosial di antara umat beragama pada prinsipnya tidak terbatas pada hubungan timbal balik antara individu dengan individu tetapi interaksi itu dapat diungkapkan pula melalui bahasa simbol yaitu, simbol-simbol yang diungkapkan melalui karya seni atau dalam bahasa ritual tertentu. Simbol-simbol yang ada kemudian diinkulturasikan dan menjadi agen komunikasi non verbal sehingga sanggup mendorong pertumbuhan nilai-nilai lokal kerukunan antarumat beragama yang menyatukan semua umat beragama. Selanjutnya bahasa simbol ini diinterpretasi dan makna dapat dijadikan daya kekuatan dalam mewujudkan komunikasi di antara warga masyarakat Desa Buduk. Manakala nilai-nilai lokal dasar ini diabaikan atau tidak dilestarikan oleh masyarakat dan generasi penerusnya maka bukan tidak mungkin masyarakat akan kehilangan karakternya. Cita-cita membentuk karakter masyarakat yang rukun dan damai perlahan-lahan punah. Tentu saja hal ini tidak diinginkan oleh siapapun sebab hal mendasar yang perlu ada dalam kehidupan bersama pada konteks kehidupan masyarakat yang majemuk adalah nilai-niliai lokal yang melekat dalam kehidupan masyarakat harus senantiasa dipertahankan. 


\section{Pengintegrasian Pengetahuan dan Nilai-nilai Kerukunan antarumat Beragama di Desa Buduk dalam kurikulum pembelajaran IPS.}

Dalam kedudukannya sebagai lembaga akademisi, sekolah memiliki peran dan fungsi yang sangat strategis dalam upaya melestarikan pengetahuan dan nilai-nilai lokal kerukunan antarumat beragama. Sekolah selain berfungsi sebagai lembaga pendidikan di mana para peserta didik menimba bermacam ilmu pengetahuan tetapi sekolah serentak menjadi tempat pembudayaan pengetahuan, nilai-nilai, tradisi, kebiasaan dan habitus masyarakat. Karena itu sekolah perlu membuka ruang bagi pengintegrasian pengetahuan dan nilai-nilai lokal dari lingkungan masyarakat. Salah satu di antaranya adalah pengetahuan dan nilai-nilai kerukunan antarumat beragama. Sekolah melalui pembelajaran IPS, kiranya melihat peluang ini dan mulai memanfaatkan pengetahuan dan nilai-nilai lokal kerukunan antarumat beragama di lingkungan masyarakat untuk tujuan pendidikan. Sekolah perlu memperluas kajian akademiknya sampai ke lingkungan masyarakat. Karena itu, sekolah dan lingkungan masyarakat adalah dua realitas sosial yang berbeda namun satu kesatuan yang tak terpisahkan. Proses pengintegrasian itu dilakukan dengan cara memilih tema yang tepat yang sudah tersedia di dalam silabus kurikulum 2013, seperti "memahami pengertian dinamika interaksi manusia dengan lingkungan alam, sosial, budaya, dan ekonomi". Pemilihan tema itu penting supaya sesuatu yang ditemukan di lingkungan masyarakat selaras dengan konten dan konteks silabus. Atas dasar itu, pengintegrasian pengetahuan dan nilai-nilai lokal kerukunan antarumat beragama perlu untuk dilakukan mengingat pengetahuan dan nilai-nilai lokal tersebut memiliki berkontribusi dalam pembentukan jati diri dan karakter peserta didik. Pendidikan IPS mestinya melihat peluang ini, sehingga cita-cita reformasi dan konstruktivisme dalam pembelajaran IPS semakin terwujud. Inovasi pembelajaran baik materi, metode, media dan sumber belajarnya rasa-rasanya mendesak untuk dilakukan. Sekolah semestinya memacu diri untuk memanfaatkan berbagai sumber pembelajaran dengan menggunakan teknik yang lebih inovatif, konstruktivis dan bermutu sehingga upaya pelestarian pengetahuan dan nilai-nilai lokal dapat mewujudkan kerukunan antarumat beragama.

\section{SIMPULAN DAN SARAN}

Faktor yang mendukung kerukunan antarumat beragama di Desa Buduk, ditinjau dari sudut pandang sosial budaya dan religius adalah pertama, pengetahuan dan nilai-nilai lokal kerukunan antarumat beragama menjadi landasan dasar dan menjadi hal fundamental bagi masyarakat dalam menciptakan kehidupan bermasyarakat yang rukun dan damai. Pengetahuan dan nilai lokal ini menyatukan masyarakat dari berbagai latarbelakang keyakinan agama, budaya, adat-istiadat dan etnik yang berbeda satu sama lain. Kedua, karena pengetahuan dan nilai-nilai lokal ini menjadi hal mendasar dan fundamental, maka perlu dilestarikan dan dalam hal ini sekolah memiliki tanggung jawab dalam melestarikannya terutama melalui kurikulum pendidikan IPS. Ketiga, pengintegrasian pengetahuan dan nilainilai lokal kerukunan antarumat beragama ke dalam kurikulum merupakan suatu strategi inovatif dan bermakna dalam memanfaatkan lingkungan masyarakat sebagai sumber belajar IPS. Pengintegrasian akan dilakukan dalam bentuk Rancangan Pelaksanaan Pembelajaran (RPP) dan modul pembelajaran. Karena itu, Pertama, hasil pengintegrasian pengetahuan dan nilai-nilai lokal kerukunan antarumat beragama ini dapat dimanfaatkan oleh guru sebagai refrensi dalam mengemas materi pembelajaran yang berbasis lingkungan masyarakat. Kedua, pengitegrasian pengetahuan dan nilai-nilai lokal ini membantu para peserta didik dan guru memahami masyarakat serta mambantu membentuk karakter peserta didik. Ketiga, perlu mensosialisasikan pengetahuan dan nilai-nilai lokal ini manfaat daripada pengembangan materi berbasis lingkungan masyarakat ini kepada para guru. Keempat, model pengintegrasian ini dapat menjadi referensi tambahan bagi peneliti lain/sejenis. 


\section{DAFTAR PUSTAKA}

Bertens, K. 2011. Etika. Jakarta: Gramedia

Drost, J.I.G.M. Sekolah Mengajar atau Mendidik? Yogyakarta: Kanisius.

Gunawan, Rudy. 2013. Pendidikan IPS, Filosofi, Konsep dan Aplikasi. Bandung: Alfabeta.

Kertih, Wayan I. 2012. Pendidikan IPS; Apa, Mengapa, dan Bagaimana (Suatu Kajian Analisis-Reflektif dari Folosofis hingga Praktik Pembelajaran). Bandung: UPI

Lasmawan, Wayan. 2016. Pendidikan IPS. Singaraja: Mediakom Indonesia Press Bali.

Mudyahardjo, Redja. 2009. Pengantar Pendidikan: Sebuah Studi Awal tentang Dasar-dasar Pendidikan pada Umumnya dan Pendidikan di Indonesia. Jakarta: Rajawali Press.

Sarosa Samiaji. 2012. Penelitian Kualitatif: Dasar-dasar. Jakarta: PT Indeks.

Soelaeman, Munandar M. 2001. Ilmu Sosial Dasar Teori dan Konsep IImu Sosial. Jakarta: Refika Aditama.

Sukadi, Sanjaya, Bagus Dewa, Kertih Wayan I. 2009. "Rekonstruksi Pemikiran Belajar dan Pembelajaran PKn SD sebagai Yadnya dalam Rangka Perwujudan Dharma Agama dan Dharma Negara Berbasis Konstruktivisme" (Artikel). Undiksha: Fakultas IImu Sosial.

Tilaar, R. A. H. 2000. Pendidikan, Kebudayaan, dan Masyarakat Madani Indonesia: Strategi Reformasi Pendidikan Indonesia. Bandung: PT. Remaja Rosdakarya.

Ulum, Raudatul dan Budiyono, (ed.). 2016. (Survey) Kerukunan Umat Beragamadi Indonesia. Jakarta: Puslitbang Kehidupan Beragama Kementerian Agama RI. 